\title{
Nutritional composition, antioxidant assay and $\alpha$-glucosidase inhibitory flavonoids from the fruits of Carissa edulis Vahl (Apocynaceae)
}

\author{
Olalekan Stephen OJERINDE ${ }^{1 *}$, Dalen Dafam GWATAU ${ }^{2}$, Kakjing Dadul FALANG ${ }^{3}$, \\ Patricia O. ODUMOSU ${ }^{1}$ and Jacob Adegboyega KOLAWOLE ${ }^{1}$
}

\author{
${ }^{1}$ Department of Pharmaceutical and Medicinal Chemistry, University of Jos, Jos. Nigeria. \\ ${ }^{2}$ Department of Pharmacognosy and Alternative Medicine, University of Jos, Jos. Nigeria. \\ ${ }^{3}$ Department of Pharmacology and Toxicology, University of Jos, Jos. Nigeria.
}

Received $1^{\text {st }}$ December 2020; Accepted $3^{\text {rd }}$ March 2021

\begin{abstract}
Carissa edulis Vahl (Apocynaceae) is a plant whose leaves, roots and fruits are traditionally employed for the treatment of malaria, microbial infections, headache, cough, fever and ulcer among many others. Fresh fruits of Carissa edulis were crushed and extracted with $70 \%$ methanol for 72 hours to obtain $\mathrm{MeOH}$ extract. Proximate analysis as well as mineral composition of the fresh fruits were determined. Total phenolic content (TPC), total flavonoids content (TFC) and antioxidant activity (DPPH, FRAP \& Ferrous chelating) of the MeOH extract were determined, while the $\alpha$-glucosidase inhibitory activity of the extract was conducted using bioautographic assay. The structure of compounds isolated were elucidated by 1D NMR spectroscopic analysis and high-resolution mass spectrometric (HRESIMS) data. The results showed that the nutritive value of the fresh Carissa edulis is 43.43 $\mathrm{kcal} / 100 \mathrm{~g}$, while the extract demonstrated good antioxidant activities $\left(\mathrm{DPPH}, \mathrm{IC}_{50}=87.98 \mu \mathrm{g} / \mathrm{ml} ; \mathrm{FRAP}, \mathrm{EC}_{50}=\right.$ $464.33 \mu \mathrm{g} / \mathrm{ml} \&$ Ferrous chelating, $\mathrm{EC}_{50}=294.55 \mu \mathrm{g} / \mathrm{ml}$ ). Further study of the $\mathrm{MeOH}$ extract of the fruit led to the isolation of rhamnetin-3- $\beta$-D-glucopyranoside, peonidin-3-rutinoside and malvidin-3-O- $\beta$-D-( 6 "-acetylglucoside). These results suggest that the fruits of Carissa edulis are nutritious and possess potential antidiabetic effect which corroborated the ethnomedical uses of the fruits.
\end{abstract}

Keywords: Carissa edulis; $\alpha$-Glucosidase; Anthocyanins; Nutritional composition; Antioxidant properties

\section{INTRODUCTION}

Diabetes Mellitus is a chronic metabolic disease characterized by elevated blood glucose level, resulting in several complications such as retinopathy, nephropathy, neuropathy, cataract and atherosclerosis [1-3]. Type 2 diabetes mellitus- (T2DM), is a life-threatening disease which accounts for $90 \%$ of diabetic patients worldwide [4]. Postprandial hyperglycemia has been associated with the development of T2DM which also accounts for the complications in diabetes [4,5]. Currently, $\alpha$ glucosidase inhibitors (Acarbose, miglitol and voglibose) are employed to slow down the activity of $\alpha$-glucosidase enzymes thereby decreasing after-meal glucose levels [1]. The management of T2DM with $\alpha$-glucosidase

*Correspondence. E-mail: ojerindeo@unijos.edu.ng Tel: +234-8036135408.

ISSN 0189-8442

2021. Published by Faculty of Pharmaceutical Sciences, University of Jos, Nigeria. Under Creative Commons Attribution-Non-Commercial 4.0 International License. https://creativecommons.org/licenses/by-nc/4.0/ 
inhibitors has been associated with some side effects which include abdominal distension, flatulence, diarrhea $[1,3]$. Therefore, there is a dire need to source for alternative $\alpha$ glucosidase inhibitors from natural products. Flavonoids, such as anthocyanins and flavonols have remained the predominant flavonoids present in berries and red grapes, which are generally present in their glycosylated form. Generally, the (flavonoids) are known for their significant antioxidant activities and they account for over $60 \%$ of dietary phenolic content [6,7]. Anthocyanins and other members of flavonoids are potential $\alpha$-glucosidase inhibitors which are present in great quantity in highly coloured fruits such as berries. $[6,8,9]$. Berries are fruits that can be eaten whole due to their small nature, having very tiny seeds or seedless [6]. They are highly coloured due to the presence of anthocyanins which serve as natural antioxidants. Consumption of berries are known to lower post-prandial glucose due to the presence of bioactive compounds. [10-13]. Carissa edulis Vahl is a plant which belongs to the family of Apocynaceae. It is found in Northern Nigeria, Mali, Guinea, Ghana, Togo, Madagascar, Somalia, India, Botswana, Cameroun, Benin, Cambodia, Japan, Myanmar and China [14]. It is commonly called 'Cizaki' or 'Lemun tsuntsu' among Hausa people of Northern Nigeria. It is a thorny shrub that bears sweet edible fruits with tiny seeds. Various parts of the plant, especially the roots are used in ethnomedicine for the treatment of disease conditions such as epilepsy, headache, toothache, cough, rheumatism, fever, sickle cell anaemia, gonorrhea, syphilis, helminthiasis, hernia oedema, ulcer and rabies [14-18].

The LC-MS analysis of the methanolic extract of the fruits revealed the presence of phenolic acids which include: quinic acid, protocatechuoyl-hexose, neochlorogenic acid, chlorogenic acid, cryptochlorogenic acid and dicaffeoylquinic acid while flavonoids identified include: procyanidin dimer, catechin, procyanidin trimer, quercetin-3-Oglucosyl-xyloside, quercetin-3-Orobinobioside, rutin, isoquercitrin and quercetin-3-OH-3-methylglutaryl-glucoside [6]. There are currently no reports elaborating on the $\alpha$-glucosidase inhibitory activity of the fruits of Carissa edulis as well as the isolation of the compounds responsible for the activity. Therefore, this study aims at isolating the $\alpha$ glucosidase inhibitors from the fruits of Carissa edulis using bioassay-guided fractionation approach via bioautographic assay.

\section{EXPERIMENTAL METHODS}

Chemicals and reagents. Thin-Layer Chromatography (TLC) was performed using pre-coated normal silica gel $\mathrm{F}_{254}$ and $\mathrm{RP}-\mathrm{C}_{18}$ $\mathrm{F}_{254 \mathrm{~S}}$ (Merck). Column chromatography (CC) procedures were performed using silica gel 230-400 mesh (Merck, Darmstadt, Germany). Preparative Reverse phase High Performance Liquid Chromatography (prep.RP-HPLC) was performed using Shimadzu LC-10AT pumps coupled with a Shimadzu SPD-M10A diode array detector, a SCL-10A system controller, and a Phenomenex $5 \mu \mathrm{M}, 100 \AA$, Luna $\mathrm{C}_{18}(250$ X $10 \mathrm{~mm}$ ). Solid Phase Extraction (SPE) was conducted with Thermo Scientific Hypersep $\mathrm{C}_{18} 500 \mathrm{mg} 3 \mathrm{~mL} .{ }^{1} \mathrm{H}$ NMR spectra was recorded on a Bruker Avance 500 Spectrometer in Acetone-d, $\mathrm{CD}_{3} \mathrm{OCD}_{3}$ with Trimethylsilane (TMS) as internal standard. An Agilent 6220 LC-TOF-MS mass spectrometer was used to obtain high resolution mass spectra (HR)-ESI-MS in the positive ion mode. 1,1-Diphenyl-2picrylhydrazyl radical (DPPH), 2,4,6-tris(2pyridyl)-S-triazine (TPTZ), $\alpha$-glucosidase from baker's yeast (product no. G5003), pnitrophenyl- $\alpha$-D-glucopyranoside,

Ethylenediamine tetraacetic acid (EDTA), Dimethylsulfoxide (DMSO), gallic acid, rutin, Folin-coicalteu reagent, sodium carbonate and Ferrozine were purchased from Sigma-Aldrich (St. Louis, MO, USA). 
Preparation of extract. The fruits of Carissa edulis were purchased from an open market in Tomato Market, Farin-gada, Jos, Plateau State between May and August, 2017. They were identified and authenticated as Carissa edulis by Mallam Umar S. Gallah of the Herbarium Unit, Department of Biological Sciences, Ahmadu Bello University, Zaria with a voucher specimen number (ABU 900086). The fruits were washed, freeze dried, crushed and macerated with $70 \%$ methanol for $72 \mathrm{~h}$ and filtered using Whatman filter paper No. 1. The filtrate was dried in vacuo to obtain a brown gummy extract. The extract was kept and stored at $-10^{\circ} \mathrm{C}$ until further use.

Determination of proximate and mineral composition. The proximate analysis of Carissa edulis fruits for percentage moisture content, ash content, crude protein, crude fat, crude fiber and total solid were determined using the standard Association of Official Analytical Chemists (AOAC), 2019 methods [19](AOAC, 2019). The carbohydrate content was determined by difference, also according to AOAC (2019) method. The mineral analysis was carried out with the aid of atomic absorption spectrophotometer (AAS).

Determination of total phenolic content. Total phenolic content of the methanolic extract of Carissa edulis was evaluated by a colorimetric method utilizing Folin-Ciocalteu reagent according to the method described in the published report of Odumosu et al. 2015 [20]. Samples containing polyphenols are reduced by the Folin-Ciocalteu reagent thereby producing blue coloured complex. The phenolic concentration of extract was evaluated from a gallic acid calibration curve. A volume equivalent to $500 \mu \mathrm{L}$ aliquots of 10 , $20,30,40,50$, and $60 \mu \mathrm{g} / \mathrm{mL}$ methanolic gallic acid solutions were mixed with $2.5 \mathrm{~mL}$ FolinCiocalteu reagent (diluted ten-fold) and $2.5 \mathrm{~mL}$ (75 g/L) sodium carbonate. The tubes were vortexed for $10 \mathrm{sec}$ and allowed to stand for 2 $\mathrm{h}$ at $25^{\circ} \mathrm{C}$. After incubation at $25^{\circ} \mathrm{C}$ for $2 \mathrm{~h}$, absorbance was measured at $765 \mathrm{~nm}$ against reagent blank using the Shimadzu UV-Vis Spectrophotometer 1650 (Japan). Total phenolic content was expressed as mg gallic acid equivalent/g using the following equation based on the calibration curve: $\mathrm{y}=0.0086 \mathrm{x}+$ $0.0583, \mathrm{R}^{2}=0.9851$, where $\mathrm{x}$ was the absorbance and $\mathrm{y}$ was the gallic acid equivalent $(\mathrm{mg} / \mathrm{g})$. A similar procedure was adopted for the extract as described above in the preparation of calibration curve. All determinations were performed in triplicate. Total phenolic content was expressed as milligrams of gallic acid equivalent (GAE) per $\mathrm{g}$ of extract.

\section{Determination of total flavonoid content.}

The total flavonoid content of the methanolic extract of Carissa edulis was measured by employing aluminium chloride colorimetric assay according to earlier reported methods [20]. In the procedure an aliquot $(1 \mathrm{~mL})$ of extract (40 mg) or rutin standard solution with the following concentrations (10, 20, 40, 60, 80 \& $100 \mu \mathrm{g} / \mathrm{mL}$ ) was added to a $10 \mathrm{~mL}$ volumetric flask containing $4 \mathrm{~mL}$ of distilled water. To the flask, $300 \mu \mathrm{L}$ of $5 \% \mathrm{NaNO}_{2}$ and $300 \mu \mathrm{L}$ of $10 \% \mathrm{AlCl}_{3}$ were added. After 6 min, $2 \mathrm{~mL}$ of $1 \mathrm{M} \mathrm{NaOH}$ was added and the total volume was brought to $10 \mathrm{~mL}$ by the addition of $2.4 \mathrm{~mL} \mathrm{H}_{2} \mathrm{O}$. The solution was vortexed to mix the mixture thoroughly and the absorbance was measured at $510 \mathrm{~nm}$ against reagent blank using the UV-Vis Spectrophotometer 1650 Shimadzu, Japan. The total flavonoid contents of the extract were expressed as mg rutin equivalents $\mathrm{mg}$ (RE)/g of extracts. All treatments were carried out in triplicate. The results were calculated using the standard calibration curve of rutin in methanol $\left(\mathrm{R}^{2}=\right.$ 0.9905) and expressed as rutin equivalents (RE $\mathrm{mg} / \mathrm{g})$.

Determination of antioxidant activity. The antioxidant activity of the extract was evaluated using three different methods.

DPPH radical scavenging activity. The antioxidant activity of extract on the stable 
radical 1,1-diphenyl-2-picrylhydrazyl (DPPH) was determined according to the method earlier reported [20]. About $12.5 \mathrm{mg}$ of the extract was dissolved in methanol using $25 \mathrm{~mL}$ volumetric flask. The following concentrations of the extract were prepared 500, 250, 125, $62.50,31.25,15.62,7.8125,3.91,1.95$, and $0.98 \mu \mathrm{g} / \mathrm{mL}$. All the solutions were prepared with methanol as solvent. A quantity $(2 \mathrm{~mL})$ of each prepared concentration was mixed with 4 $\mathrm{mL}$ of $50 \mu \mathrm{M}$ DPPH solution in methanol. Experiment was done in triplicate. The mixture was vortexed for $10 \mathrm{~s}$ to homogenize the mixture and test tubes were incubated for 30 min at room temperature in the dark. Thereafter, the absorbance was measured at $515 \mathrm{~nm}$ on a UV-Vis spectrophotometer (Shimadzu, UV-1620PC, Japan). Lower absorbance of the reaction mixture indicates higher free radical scavenging activity. Vitamin $\mathrm{C}$ and rutin were used as standards with the following concentrations $100,50,25$, $12.5,6.25,3.125,1.563,0.7812,0.391$ and $0.195 \mu \mathrm{M}$. Blank solution was prepared by mixing $2 \mathrm{~mL}$ of methanol with $4 \mathrm{~mL}$ of $50 \mu \mathrm{M}$ DPPH solution. The difference in absorbance between the test and the control (DPPH in methanol) was calculated and expressed as \% scavenging of DPPH radical. The capability to scavenge the DPPH radical was calculated by using the following equation

$$
\% \text { inhibition }=\frac{A b s_{\text {control }}-A b_{\text {sample }}}{A b s_{\text {control }}} \times 100
$$

Finally, the $\mathrm{IC}_{50}$ value, defined as the concentration of the sample leading to $50 \%$ reduction of the initial DPPH concentration, was calculated from the separate linear regression of the mean of the antioxidant activity against concentration of the test extract $(\mu \mathrm{g} / \mathrm{mL})$.

Ferric Reducing Antioxidant Potential (FRAP). The ferric reducing property of the extract was determined by using the assay earlier reported [21,22]. Briefly, $3.8 \mathrm{~mL}$ of a freshly prepared solution of FRAP reagent (mixture solutions: $300 \mathrm{mM}$ acetate buffer, $\mathrm{pH}$ 3.6, $10 \mathrm{mM} \mathrm{TPTZ}$ in $\mathrm{HCl}(40 \mathrm{mM})$ and $\mathrm{FeCl}_{3}$
$(20 \mathrm{mM})$ at a ratio of $10: 1: 1$ at $\left.37{ }^{\circ} \mathrm{C}\right)$ was added to $200 \mu \mathrm{L}$ of the extracts with different concentrations $(0.98-500 \mu \mathrm{g} / \mathrm{mL})$. The mixture was vortexed and incubated for $30 \mathrm{~min}$ at room temperature in the dark. After the incubation, the absorbance of the coloured product (ferrous tripyridyl triazine complex) was read at $595 \mathrm{~nm}$ using UVSpectrophotometer (Shimadzu, Japan). Results are expressed in $\mu \mathrm{MFe} \mathrm{II} / \mathrm{g}$ of dry mass which were obtained from the standard curve prepared.

Ferrous chelating activity. Chelating ability was determined according to the method of Yaltriak et al. 2009 [23]. One milliliter of extract at different concentrations $(0.98-500$ $\mu \mathrm{g} / \mathrm{ml}$ ) in methanol was mixed with $3.7 \mathrm{ml}$ of methanol and $0.1 \mathrm{ml}$ of $2 \mathrm{mM}$ ferrous chloride. The reaction was initiated by the addition of $200 \mu \mathrm{l}$ of $5 \mathrm{mM}$ ferrozine and vortexed for 10 s. After $10 \mathrm{~min}$ at room temperature, the absorbance of the mixture was determined at $562 \mathrm{~nm}$ against blank. The results were expressed as percentage of inhibition of the ferrozine $-\mathrm{Fe}^{2+}$ complex formation. The percentage of inhibition of the ferrozine- $\mathrm{Fe}^{2+}$ complex formation was calculated using the formula given below:

$$
\% \text { inhibition }=\frac{A b_{\text {control }}-A b s_{\text {sample }}}{A b s_{\text {control }}} \times 100
$$

where $\mathrm{Abs}_{\text {control }}$ is the absorbance of the ferrozine- $\mathrm{Fe}^{2+}$ complex and $\mathrm{Abs}_{\text {sample }}$ is the absorbance in the presence of methanolic extract of Carissa edulis. EDTA was used as a positive control for comparison. Then $\mathrm{EC}_{50}$ values $(\mu \mathrm{g} / \mathrm{ml})$, the effective amount of the extract needed to chelate ferrous ion by $50 \%$, were determined from the plotted graph of scavenging activity against the concentration of the extract.

TLC bioautographic assay. TLC bioautographic assay was carried out as described previously in terms of reaction principle and response system [24,25] but with slight modifications. First, the concentration of $\alpha$-glucosidase was increased from $10 \mathrm{U} / \mathrm{mL}$ to 
$15 \mathrm{U} / \mathrm{mL}$ while the concentration of the substrate was reduced. Second, the developed TLC plate was dipped into the reaction solutions (the enzyme and substrate solutions, without the inclusion of colouration solution), instead of being sprayed with reaction solutions. Lastly, the conditions for enzyme incubation were changed from room temperature for $60 \mathrm{~min}$ to $38^{\circ} \mathrm{C}$ for $25 \mathrm{~min}$. Briefly, $\alpha$-glucosidase (375 U) was dissolved in $25 \mathrm{~mL}$ of buffer solution (Potassium phosphate buffer, $\mathrm{pH}$ 7.2). $45 \mathrm{mM}$ of $\mathrm{p}$ nitrophenyl- $\alpha$-D-glucopyranoside was prepared in potassium phosphate buffer, $\mathrm{pH}$ 7.2. Equal volumes of the enzyme solution and the substrate solutions were mixed together. The developed TLC plate was dried under a stream of cold air for complete removal of the solvent and thereafter, dipped into the reaction solution for 5 second. For enzyme incubation, the plate was laid flat on a glassy material with a close contact with a thermostat-hot plate set at $38^{\circ} \mathrm{C}$ for $15 \mathrm{~min}$ until the yellow background developed by the cleavage of $p$-nitrophenyl- $\alpha$ D-glucopyranoside into p-nitrophenyl is decolourized to form white spots against the yellow background.

Fractionation and isolation. A mass of fifty gram $(50 \mathrm{~g})$ of the extract was suspended in $\mathrm{MeOH}: \mathrm{H}_{2} \mathrm{O}(9: 1,1000 \mathrm{~mL})$ and partitioned into hexane $(500 \mathrm{~mL} \mathrm{X} \mathrm{2)}$ and aqueous $\mathrm{MeOH}$ fraction. Thereafter, aqueous $\mathrm{MeOH}$ fraction was suspended in $\mathrm{MeOH}: \mathrm{H}_{2} \mathrm{O}(60: 40)$ and partitioned with $\mathrm{CH}_{2} \mathrm{Cl}_{2}(500 \mathrm{~mL} \mathrm{X} \mathrm{3)}$ to obtain $\mathrm{CH}_{2} \mathrm{Cl}_{2}$ and aqueous $\mathrm{MeOH}$ fractions. Furthermore, the aqueous $\mathrm{MeOH}$ fraction was suspended in $\mathrm{MeOH}: \mathrm{H}_{2} \mathrm{O}$ (40:60) and partitioned into ethyl acetate to afford EtOAc and aqueous $\mathrm{MeOH}$ fractions. The fractions (hexane, $\mathrm{CH}_{2} \mathrm{Cl}_{2}, \mathrm{EtOAc}$ and aqueous) were tested for $\alpha$-glucosidase inhibitory activity using bioautography method. $\mathrm{CH}_{2} \mathrm{Cl}_{2}$ fraction demonstrated the highest inhibitory activity. The $\mathrm{CH}_{2} \mathrm{Cl}_{2}$ fraction was chromatographed on Hypersep $\mathrm{C}_{18}$ Solid Phase Extraction (SPE) using $80-100 \% \mathrm{MeOH}$ to elute, this afforded three sub-fractions (CE1 - CE3). Sub-fraction CE1 (207.6 mg) was chromatographed using preparative RP-HPLC (MeOH: $\left.\mathrm{H}_{2} \mathrm{O}, 60: 40\right)$ to obtain three compounds; CE 11(4.5 mg), CE 12 (2.1 mg), and CE 13 (1.5 mg). The compounds were subjected to spectroscopic analysis, ${ }^{1} \mathrm{H}$ NMR and mass spectrometric analysis.

\section{RESULTS AND DISCUSSION}

The result of the proximate analysis of Carissa edulis fruits is presented on Table 1 below. The moisture content was found to be $71.96 \%$. Though, the moisture content is not as high as the moisture content of the others species of Carissa. According to earlier reports, Carissa species contain a range of moisture content between $70.00-90.59 \%$. [26,27].

The high moisture content has been implicated for the susceptibility and vulnerability of the fruits to spoilage if not properly stored due to the increasing microbial action. [28]. High moisture content in fruits reduces the shelf - life of fruits by enhancing microbial growth on the fruits while low moisture content prevents the microbial growth thereby elongating the shelf-life of the fruits. [29]. The crude protein content was found to be $1.07 \%$ which is higher than the earlier report on Carissa edulis $(0.3 \%)$ in Uganda [30] and Carissa macrocarpa (0.74\%) [31]. In another study, Chauhan et al. 2015 [32] reported crude protein content of $2.07 \%$. The protein content implies that the fruits can be used for regulating body processes and formation of antibodies to fight infections. Crude fiber content have been reported in blueberries generally to range between 9.27 $21.61 \mathrm{~g} / \mathrm{kg}$. [33]. In this present study, crude fiber was found to be $15.70 \%$ which is similar to the fiber content in Carissa spinarum [32] but higher than the earlier reports by Musinguzi et al. 2007 [30] for Carissa edulis $(2.65 \%)$. The crude fiber content was found to be relatively high $(15.70 \%)$ which implies that 
the fruits might be useful in making digestibility preparations due to high fiber content to aid digestion in humans [29]. Crude fiber content measures the indigestible components such as cellulose and lignin contained in the fruits [29]. The ash content was found to be $(0.52 \%)$ which is similar to the earlier study reported by Souilem et al. 2019 [31] concerning the fruits of Carissa macrocarpa that was reported to contain $0.5 \%$ ash content. The ash content measures the amount of minerals available or contained in a fruit. The carbohydrate content $(10.49 \%)$ is lower than that of the Carissa macrocarpa (16.40\%) and Carissa spinarum (18.66\%) reported by Souilem et al. (2019) [31] and Chauhan et al. (2015) [32] respectively, meanwhile, the sugar content (17.50 g) was higher than that of Carissa macrocarpa [31]. The total solid content is $28.04 \%$, fat $(0.3 \%)$ which is lower than that of Carissa spinarum $(1.30 \%)$ reported by Chauhan et al. 2015 [32]. Besides, the energy content is $45.43 \mathrm{kcal}$ lower than that of Carissa macrocarpa (100.3 kcal) [31].

The result for the determination of mineral content of $C$. edulis is shown on Table 2 . The mineral analysis revealed that the fruits are rich in some minerals. Sodium $(\mathrm{Na})$ has the highest value $(16.36 \mathrm{mg} / 100 \mathrm{~g})$. This is higher than what was obtained in Carissa edulis (1.79 $\mathrm{mg} / 100 \mathrm{~g}$ ) reported by Musinguzi et al., 2007 [30]. The fruits also contain $2.01 \mathrm{mg} / 100 \mathrm{~g}$ $(\mathrm{Fe}) ; 3.02 \mathrm{mg} / 100 \mathrm{~g}(\mathrm{Ca}) ; 0.051 \mathrm{mg} / 100 \mathrm{~g}$ (Zn); $0.12 \mathrm{mg} / 100 \mathrm{~g}(\mathrm{P})$ and $0.00 \mathrm{mg} / 100 \mathrm{~g}$ $(\mathrm{Pb})$.

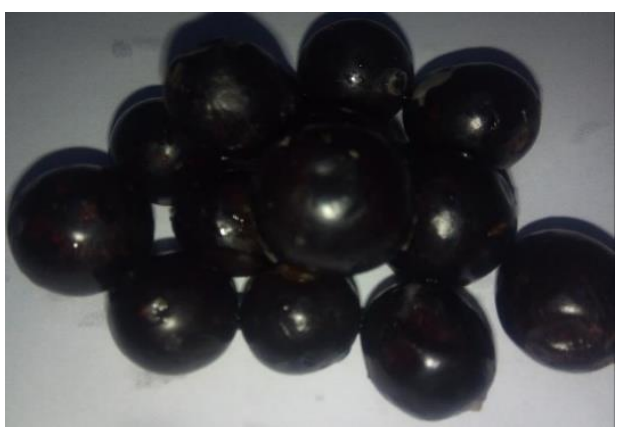

Plate 1. Carissa edulis fruits at the ripe stage

Table 1 Proximate Analysis of Carissa edulis extract

\begin{tabular}{lc}
\hline Parameters & Value \\
\hline Moisture content \% & 71.98 \\
Ash content \% & 0.52 \\
Crude protein \% & 1.07 \\
Crude Fibre \% & 15.70 \\
Fat \% & 0.36 \\
Carbohydrate \% & 10.49 \\
Energy Kcal/100 g & 45.43 \\
Sugar $(\mathrm{g})$ & 17.50 \\
Total Solid \% & 28.04 \\
\hline
\end{tabular}

Table 2: Mineral Composition of Carissa edulis extract

\begin{tabular}{lc}
\hline Mineral & Value $(\mathrm{mg} / 100 \mathrm{~g})$ \\
\hline Sodium $(\mathrm{Na})$ & 16.36 \\
Calcium $(\mathrm{Ca})$ & 0.051 \\
Iron $(\mathrm{Fe})$ & 2.01 \\
Zinc $(\mathrm{Zn})$ & 3.02 \\
Phosphorus $(\mathrm{P})$ & 0.12 \\
Lead $(\mathrm{Pb})$ & 0.00 \\
\hline
\end{tabular}


Table 3: Antioxidant Activity of Carissa edulis extract

\begin{tabular}{lccc}
\hline \multicolumn{4}{c}{$\mathrm{IC}_{50}(\mu \mathrm{g} / \mathrm{mL})$} \\
Extract & $\mathrm{DPPH}$ & Fe chelating & FRAP \\
\hline MeOH & $87.98 \pm 12.02$ & $294.55 \pm 21.68$ & $464.33 \pm 18.33$ \\
Rutin & $57.60 \pm 3.87$ & $\mathrm{ND}$ & $\mathrm{ND}$ \\
Vit. C & $0.397 \pm 0.001$ & $\mathrm{ND}$ & $68.53 \pm 5.43$ \\
EDTA & $\mathrm{ND}$ & $122.4 \pm 12.05$ & $\mathrm{ND}$ \\
\hline
\end{tabular}

Values are expressed as Mean $\pm \mathrm{SEM}, \mathrm{n}=3$. ND $=$ Not determined

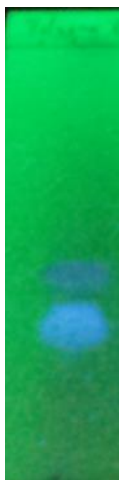

A

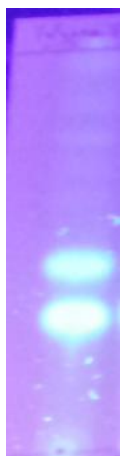

B

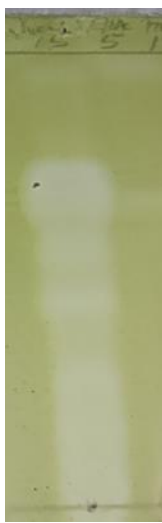

$\mathrm{C}$

Figure 3. Results of TLC of autobiography screening of $\mathrm{MeOH}$ extract from Carissa edulis.

Samples were developed in Toluene-Ethyl acetate-Acetic acid (15:5:1\%). A \& B were viewed at UV 254 and 366 $\mathrm{nm}$ respectively while $\mathrm{C}$ was derivatized with $\alpha$-glucosidase.

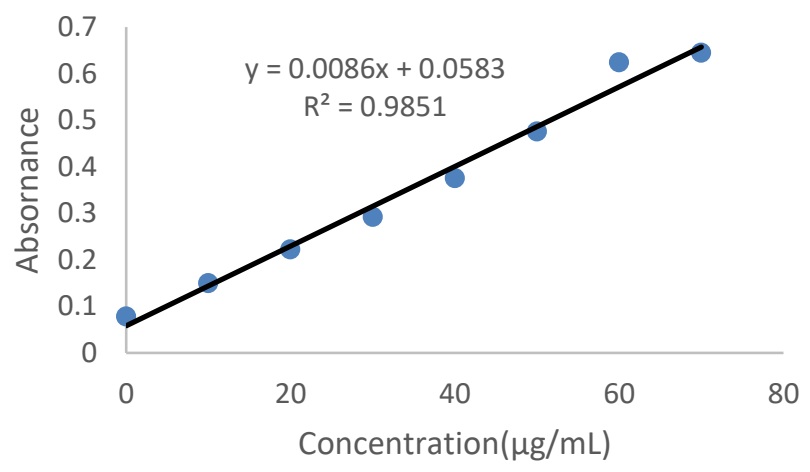

Figure 1. Calibration curve for Total Phenolic Content for Gallic acid

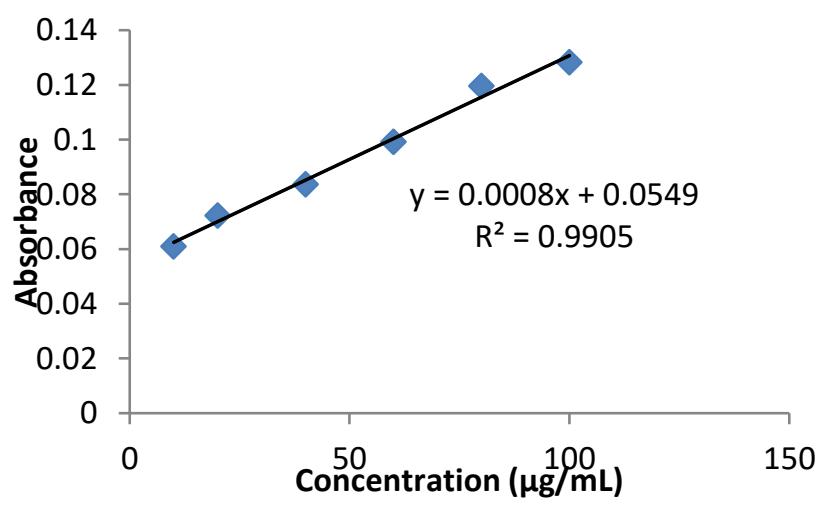

Figure 2. Calibration curve for Total Flavonoids Content for Rutin 
O.S. Ojerinde et al. / J. Pharmacy \& Bioresources 18(2), 122-132 (2021)
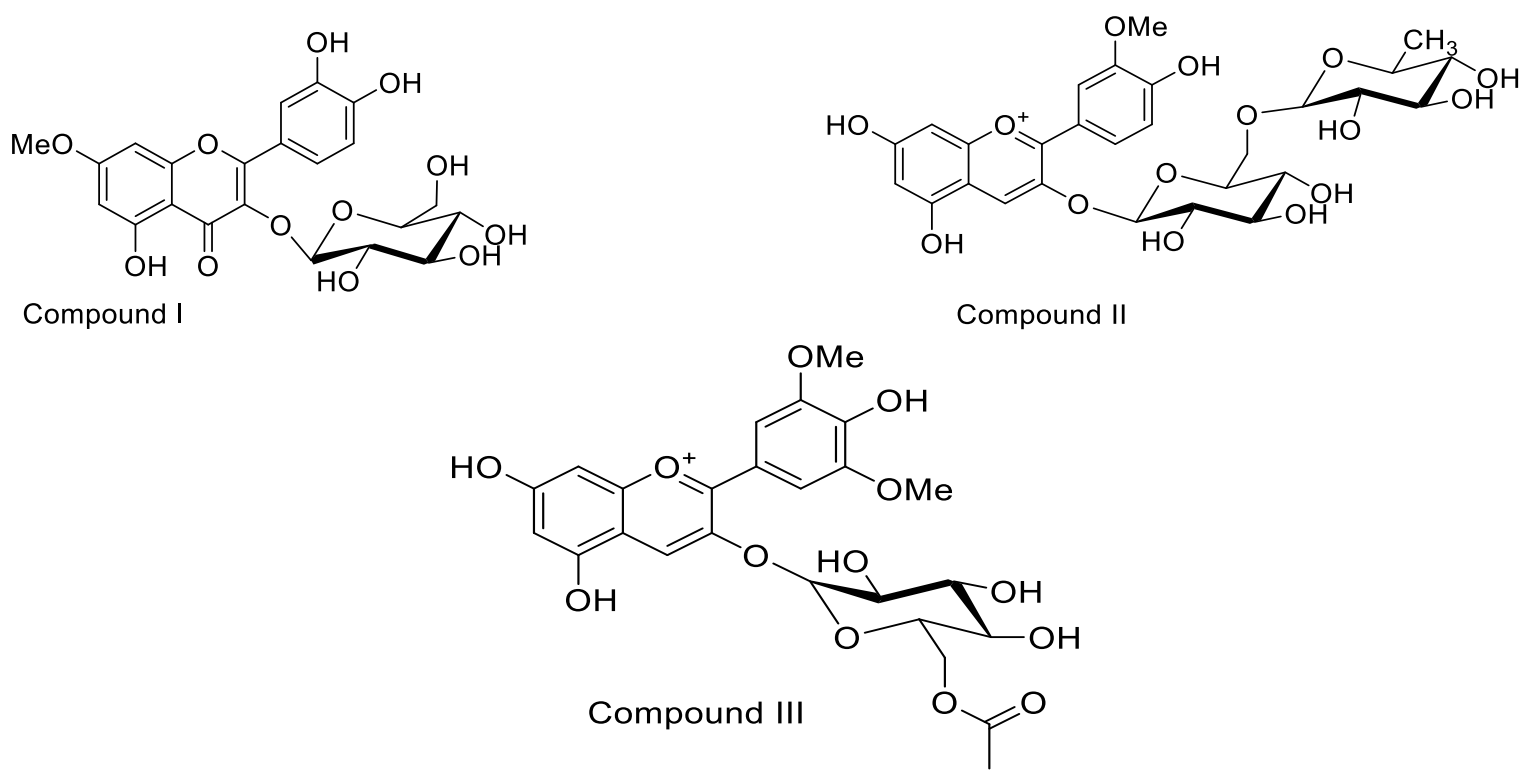

Figure 3. Structures of compounds I -III isolated from the fruits of Carissa edulis

Generally, flavonoids are phenolic compounds that possess good antioxidant properties and they constitute a high percentage of the high level of the phenolic compounds available in the plants, hence phenolic content accounts for the antioxidant effects of plant materials. The total phenolic content for the Carissa edulis fruits in this study is $18.80 \pm 0.69 \mathrm{mg} \mathrm{GAE} / \mathrm{g}$. Earlier findings showed a lower total phenolic content (6.71 mg GAE/g) in Carissa edulis fruits [6] and (5.3 mg TAE/g) in Carissa spinarum [32]. This difference may be due to the ripening stages of the fruits, fully ripened fruits contain high phenolic content compared to unripen or early ripened stage [6]. The total flavonoid content of the $C$. edulis in this study was 0.58 $\mathrm{mg} \mathrm{RE} / \mathrm{g}$ of the extract. In a separate study, Makumbele et al. 2019 [6] reported high flavonoid content for fresh fruits of Carissa edulis (5.95 mg CE/g). Meanwhile, in another study reported by Chauhan et al. 2015 [32] Carissa spinarum has a lower flavonoid content (0.153 mg QE/g).

The antioxidant activity of the methanolic extract of the Carissa edulis fruits was evaluated by employing DPPH, FRAP and Ferrous chelating assays. The results are shown on Table 3. Methanolic extract showed significant inhibitory activity of DPPH radical with $\mathrm{IC}_{50}$ values of $87.98 \pm 12.02 \mu \mathrm{g} / \mathrm{mL}$ compared with Vitamin C (0.39 \pm 0.01 $\mu \mathrm{g} / \mathrm{mL}) ; \quad$ Rutin $(57.60 \pm 3.87 \mu \mathrm{g} / \mathrm{mL})$ standards. Makumbele et al. 2019 [6] and Souilem et al. 2019 [31] reported lower radical scavenging activity for the ripened Carissa edulis and Carissa macrocarpa fruits respectively. Ferrous chelating activity of the extract was evaluated using EDTA as standard. The result on Table 3 showed good ferrous chelating with EC $_{50}$ value of $294.55 \pm 21.68$ $\mu \mathrm{g} / \mathrm{mL}$, when compared with the standard EDTA $\left(E_{50} 122.4 \pm 12.05 \mu \mathrm{g} / \mathrm{mL}\right)$. The extract demonstrated moderate chelating activity to $\mathrm{Fe}^{2+}$. The extract showed considerable reducing's power with $\mathrm{EC}_{50}$ value of $464.33 \pm 18.33 \mu \mathrm{g} / \mathrm{mL}$ compared with the standard $(68.53 \pm 5.43 \mu \mathrm{g} / \mathrm{mL})$. The high antioxidant activities of the fruits can be attributed to the presence of high phenolic contents.

The TLC plate as shown in figure 3 revealed the presence of two prominent spots when viewed at $254 \mathrm{~nm}$ while several spots ranging from $\mathrm{Rf}$ values of 0.33-0.91 were revealed when viewed at $366 \mathrm{~nm}$. Meanwhile, the $\alpha$-glucosidase inhibitory activity via bioautographic technique revealed the 
inhibitory activity of four spots with $\mathrm{Rf}$ values of $0.33,0.46,0.63$ and 0.67 .

Following the fractionation of $\mathrm{MeOH}$ extract of Carissa edulis fruits, the compounds isolated were identified as follows

Compound I: Obtained as a light-yellow powder. The positive HRESI-MS gave the [M $+\mathrm{H}]^{+}$ion at $\mathrm{m} / \mathrm{z} 479.9981$ (cald 479.9965) and the molecular formula was inferred as $\mathrm{C}_{22} \mathrm{H}_{22} \mathrm{O}_{12}$ alongside its ${ }^{1} \mathrm{H}$ NMR spectrum. The positive HRESI-MS showed the nature of the sugar present, showing ions at $\mathrm{m} / \mathrm{z} 479[\mathrm{M}$ $+\mathrm{H}]^{+} ; 317[\mathrm{M}+\mathrm{H}-162(\mathrm{Glu})]^{+}$, compound I was identified as rhamnetin-3- $\beta-\mathrm{D}$ glucopyranoside, which is the same as reported previously in literature [34]

Compound II. The positive HRESI-MS of compound II gave the $[\mathrm{M}+\mathrm{H}]^{+}$ion at $\mathrm{m} / \mathrm{z}$ 610.1825 (cald. 610.1820) and the molecular formula was inferred as $\mathrm{C}_{28} \mathrm{H}_{33} \mathrm{O}_{15}$ alongside its ${ }^{1} \mathrm{H}$ NMR spectrum. The positive HRESIMS showed the nature of the sugar present, showing ions at $\mathrm{m} / \mathrm{z} 610[\mathrm{M}+\mathrm{H}]^{+} ; 463[\mathrm{M}+$ $\mathrm{H}-146$ (Rha) $]^{+} ; 301[\mathrm{M}+\mathrm{H}-146$ (Rha) -162 $(\mathrm{Glu})]^{+}$. Compound II was identified as peonidin-3-rutinoside, which is the same as reported previously in literature $[35,36]$

Compound III. The positive HRESI-MS of compound III gave the $[\mathrm{M}+\mathrm{H}]^{+}$ion at $\mathrm{m} / \mathrm{z}$ 536.1652 (cald. 536.1452) and the molecular formula was inferred as $\mathrm{C}_{25} \mathrm{H}_{27} \mathrm{O}_{13}$ alongside its ${ }^{1} \mathrm{H}$ NMR spectrum. The positive HRESIMS showed the nature of the sugar and acetyl group present, showing ions at $\mathrm{m} / \mathrm{z} 536[\mathrm{M}+$ $\mathrm{H}]^{+} ; 493[\mathrm{M}+\mathrm{H}-43 \text { (Acetyl) }]^{+} ; 331[\mathrm{M}+\mathrm{H}$ -43 (Acetyl) -146 (Rha) $]^{+}$. Compound III was identified as malvidin-3-O- $\beta$-D- 6 "acetylglucoside), which is the same as reported previously in literature [35,37].

Conclusion. In conclusion, this study analysed the phenolic contents, nutritional, chemical composition, the antioxidant activities (DPPH, FRAP \& Fe Chelating) and $\alpha$-glucosidase inhibitory activity of the fruits of Carissa edulis using bioautographic assay. The results showed that the fruits are rich in essential nutrients, proteins, fiber, sugar, micronutrients, calories and phenolic compounds. The $\alpha$-glucosidase inhibitory activity also corroborated the ethnomedical uses of the plants for the treatment of diabetes mellitus. Likewise, compounds II \& III were reported for the first time in this species. Therefore, the ethnomedicinal use of Carissa edulis is justified for the first time by the findings of this study.

Acknowledgements. The authors acknowledge the TETFUND Research Grant Support from the University of Jos to carry out the studies reported and the support received from the Faculty of Pharmaceutical Sciences, University of Jos, Jos, Nigeria. The authors also want to acknowledge Dr. Mehdi AshrafKhorassani for recording the mass spectra, Mr. Geno Iannaccone and Dr. Narasimhamurthy Shanaiah for assistance with the NMR spectra, Department of Chemistry, Virginia Polytechnic and State University, Blacksburg, USA.

\section{REFERENCES}

1. Yang J-B, Tian J-Y, Dai Z, Ye F, Ma S-C, Wang A-G. $\alpha$-Glucosidase inhibitors extracted from the roots of Polygonum multiflorum Thunb. Fitoterapia. 2017;117: 65-70.

2. Choi CI, Lee SR, Kim KH. Antioxidant and $\alpha-$ glucosidase inhibitory activities of constituents from Euonymus alatus twigs. Ind Crops Prod. 2015;76:1055-60.

3. Alkefai NH, Ahamad J, Amin S, Sharma M, Mir SR. Arylated gymnemic acids from Gymnema sylvestre R.Br. as potential $\alpha$-glucosidase inhibitors. Phytochem Lett. 2018 ;25:196-202.

4. Zhang Y, Han FY, Wu J, Song SJ. Triterpene saponins with a-glucosidase and PTP1B inhibitory activities from the leaves of Aralia elata. Phytochem Lett. 2018; 26: 179-183.

5. Santos CMM, Freitas M, Fernandes E. A comprehensive review on xanthone derivatives as $\alpha$ glucosidase inhibitors. Eur J Med Chem. 2018; 157: 1460-1479.

6. Makumbele FP, Taylor M, Stander M, Anyasi TA, Jideani AIO, et al. Polyphenolic and Physicochemical Properties of Simple-Spined Num- 
O.S. Ojerinde et al. / J. Pharmacy \& Bioresources 18(2), 122-132 (2021)

Num (Carissa edulis) Fruit Harvested at Ripe Stage of Maturation. Molecules 2019, 24, 2630.

7. Eichholz I, Huyskens-Keil S, Kroh LW, Rohn S. Phenolic compounds, pectin and antioxidant activity in blueberries (Vaccinium corymbosum L.) influenced by boron and mulch cover. J. Appl. Bot. Food Qual. 2011, 84, 26-32.

8. Zhang J, Sun L, Dong Y, Fang Z, Nisar T, Zhao $\mathrm{T}$, et al. Chemical compositions and $\alpha$-glucosidase inhibitory effects of anthocyanidins from blueberry, blackcurrant and blue honeysuckle fruits. Food Chem. 2019;299:125102.

9. Ogawa K, Sakakibara H, Iwata R, Ishii T, Sato $\mathrm{T}$, Goda $\mathrm{T}$, et al. Anthocyanin composition and antioxidant activity of the crowberry (Empetrum nigrum) and other berries. J. Agric Food Chem. 2008;56(12):4457-62.

10. Castro-Acosta ML, Smith L, Miller RJ, McCarthy DI, Farrimond JA, Hall WL. Drinks containing anthocyanin-rich blackcurrant extract decrease postprandial blood glucose, insulin and incretin concentrations. J. Nutr Biochem. 2016;38:154-61.

11. Thilavech T, Adisakwattana S. Cyanidin-3rutinoside acts as a natural inhibitor of intestinal lipid digestion and absorption. BMC Complement Altern Med. 2019;19(1):242.

12. Chen J guang, Wu S fu, Zhang Q feng, Yin $\mathrm{Z}$ ping, Zhang L. $\alpha$-Glucosidase inhibitory effect of anthocyanins from Cinnamomum camphora fruit: Inhibition kinetics and mechanistic insights through in vitro and in silico studies. Int J Biol Macromol. 2020;143:696-703.

13. Li F, Zhang B, Chen G, Fu X. The novel contributors of anti-diabetic potential in mulberry polyphenols revealed by UHPLC-HR-ESI-TOFMS/MS. Food Res Int. 2017;100:873-84.

14. Ibrahim H, Abdulrahman EM, Shok M, Ilyas N, Musa KY, Ukandu I. Comparative analgesic activity of the root bark, stem bark, leaves, fruits and seeds of Carissa edulis VAHL (Apocynaceae). African J Biotechnol. 2007;6(10):1233-5.

15. Osseni R, Akoha S, Adjagba M, Azonbakin S, Lagnika L, Awede B, et al. In vivo Toxicological Assessment of the Aqueous Extracts of the Leaves of Carissa edulis (Apocynaceae) in Wistar Rats. Eur J Med Plants. 2016;15(1):1-10.

16. Ibrahim H, Williams FE, Salawu KM, Usman AM. Phytochemical screening and acute toxicity studies of crude ethanolic extract and flavonoid fraction of Carissa edulis leaves. Biokemistri. 2015;27(1):39-43.

17. Nedi T, Mekonnen N, Urga K. Diuretic effect of the crude extracts of Carissa edulis in rats. $J$. Ethnopharmacol. 2004;95(1):57-61.

18. Ya'u J, Yaro AH, Abubakar MS, Anuka JA, Hussaini IM. Anticonvulsant activity of Carissa edulis (Vahl) (Apocynaceae) root bark extract. $J$. Ethnopharmacol. 2008;120(2):255-8.

19. AOAC International, The Official Methods of Analysis, $21^{\text {st }}$ ed.; The Association Official Analytical Chemist International; Rockville, MD, USA, 2019.

20. Odumosu P, Ojerinde S, Egbuchiem M. Polyphenolic contents of some instant tea brands and their anti-oxidant activities. J. Appl Pharm Sci. 2015;5(9):100-5.

21. Bothon FTD, Debiton E, Avlessi F, Forestier C, Teulade JC, Sohounhloue DKC. In vitro biological effects of two anti-diabetic medicinal plants used in Benin as folk medicine. BMC Complement Altern Med. 2013;13(1):1.

22. Mukherjee S, Pawar N, Kulkarni O, Nagarkar B, Thopte S, Bhujbal A, et al. Evaluation of freeradical quenching properties of standard Ayurvedic formulation Vayasthapana Rasayana. $B M C$ Complement Altern Med. 2011;11(1):38.

23. Yaltirak T, Aslim B, Ozturk S, Alli H. Antimicrobial and antioxidant activities of Russula delica Fr. Food Chem Toxicol. 2009; 47: 2052-2056.

24. Simões-Pires CA, Hmicha B, Marston A, Hostettmann K. A TLC bioautographic method for the detection of $\alpha$ - and $\beta$-glucosidase inhibitors in plant extracts. Phytochem Anal. 2009;20(6):511-5.

25. Yang Y, Gu L, Xiao Y, Liu Q, Hu H, Wang Z, et al. Rapid identification of $\alpha$-glucosidase inhibitors from phlomis tuberosa by sepbox chromatography and thin-layer chromatography bioautography. PLoS One. 2015;10(2):1-13.

26. Santana ECFRF, Miranda AS, Ribeiro AB, Oliveira JJ, Silva M V. Proximate Composition and Mineral Content of Strawberry Coproducts. :1-6.

27. Patra PA, Chand Basak U. Nutritional and Antinutritional Properties of Carissa carandas and Cordia dichotoma, two Medicinally Important Wild Edible Fruits of Odisha. J. Basic Appl Sci Res. 2017;7(7):1-12.

28. Khan MN, Sarwar A, Bhutto S, Wahab MF. Physicochemical characterization of the strawberry samples on regional basis using multivariate analysis. Int J Food Prop. 2010;13(4):789-99.

29. Olaitan J. Proximate and Mineral Composition of Synsepalum Dulcificum Seed. Sci Res J. 2015;III(Iii):1-5.

30. Musinguzi E, Kikafunda JK, Kiremire BT. Promoting indigenous wild edible fruits to 
complement roots and tuber crops in alleviating vitamin A deficiencies in Uganda. Proc 13th ISTRC Symp. 2007;763-9.

31. Souilem F, Dias MI, Barros L, Calhelha RC, Alves MJ, Harzallah-Skhiri F, et al. Amantagula Fruit (Carissa macrocarpa (Eckl.) A.DC.): Nutritional and Phytochemical Characterization. Plant Foods Hum Nutr. 2019;74(1):76-82.

32. Chauhan A, Tanwar B, Intelli. Influence of processing on physicochemical, nutritional and phytochemical composition of Ficus carica (fig) fruit. Res J Pharm Biol Chem Sci. 2015;6(6):1474-89.

33. Carvalho MJ, Gouveia CS, Vieira AC, Pereira AC, Carvalho M, Marques JC. Nutritional and Phytochemical Composition of Vaccinium padifolium Sm Wild Berries and Radical Scavenging Activity. J Food Sci. 2017;82(11):2554-61.

34. Al-Youssef HM, Hassan WHB. Chemical constituents of Carissa edulis Vahl. Arab J Chem.
2017;10(1):109-13.

35. Veberic R, Slatnar A, Bizjak J, Stampar F, Mikulic-Petkovsek M. Anthocyanin composition of different wild and cultivated berry species. LWT Food Sci Technol. 2015;60(1):509-17.

36. Garcia-Herrera P, Pérez-Rodríguez ML, Aguilera-Delgado T, Labari-Reyes MJ, OlmedillaAlonso B, Camara M, et al. Anthocyanin profile of red fruits and black carrot juices, purees and concentrates by HPLC-DAD-ESI/MS-QTOF. Int $J$ Food Sci Technol. 2016;51(10):2290-300.

37. Azeez S, Karunakaran G, Tripathi PC, Shivashankara KS, Roy TK. Evaluation of antioxidant activity, total phenolics and phytochemical content of selected varieties of karonda fruits (Carissa carandas). Indian J Agric Sci. 2016;86(6):815-22. 